\begin{tabular}{|c|c|c|}
\hline ב & International Journal of Current Research in & \\
\hline & $\begin{array}{c}\text { Biosciences and Plant Biology } \\
\text { ISSN: } 2349-8080 \text { (Online) } \bullet \text { Volume } 3 \bullet \text { Number } 3 \text { (March-2016) }\end{array}$ & \\
\hline $\begin{array}{l}\text { EXCELLENT } \\
\text { PUBLISHERS }\end{array}$ & Journal homepage: www.ijcrbp.com & 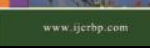 \\
\hline
\end{tabular}

\title{
Antibacterial Efficacy of Acacia nilotica (L.) Pods Growing in Sudan against Some Bacterial Pathogens
}

\author{
Emad M. Abdallah* \\ Department of Laboratory Sciences, College of Sciences and Arts at Al-Rass, Qassim University, P. O. Box 53, Saudi Arabia \\ *Corresponding author.
}

\begin{abstract}
A b stract
Acacia nilotica is a plant native to the Nile basin region, widely spread in central and northern parts of Sudan. It has been mentioned in Sudanese folk medicine to be effective against a variety of diseases. The methanol extract of the pods of Acacia nilotica was tested against four human bacterial pathogens using disc diffusion method, MIC and MBC tests. The results revealed that the extract exhibited a broader spectrum of antibacterial activity and revealed potent bactericidal effect at high concentrations (up to $100 \mathrm{mg} / \mathrm{ml}$ ) and bacteriostatic at lower concentrations (as low as $12.5 \mathrm{mg} / \mathrm{ml}$ ). In general, all tested bacteria were susceptible, however the tested gram positives (Bacillus cereus ATCC 11778 and Staphylococcus aureus) were much more susceptible than the gram negatives (Escherichia coli and Acinetobacter baumannii), supporting the traditional medical application and suggest it as a source for new antibacterial drugs.
\end{abstract}

\section{Article Info}

Accepted: 09 February 2016

Available Online: 06 March 2016

\section{Ke y w o r d s}

Acacia nilotica

Antibacterial activity

Disc diffusion

Methanol extract

Minimum bactericidal concentration

Minimum inhibitory concentration

Phytochemicals

\section{Introduction}

Medicinal plants are still playing a major role in the traditional medicine systems and to some extent modern medicine, being represented rich source of renewed natural products of therapeutic ability (Abdallah, 2011). Although, modern medicine relies mainly on synthetic or chemical drugs, but still up to $25 \%$ of all modern medicines are originally produced from higher plants (Ackerknecht, 1973). Up to 80\% of the world population are still depending on medicinal plants for primary health care, the majority of this ratio is found in the developing countries and this popularity is related to cultural acceptability and affordable price (Kumar, 2015). Recently, there is an increasing need for therapeutics with antibacterial activity because the treatment of bacterial infections is unsatisfactory, where current antibiotics are losing their efficacy against different bacterial pathogens due to overuse of antibiotics.
Although, new families of antibiotics have been introduced but they revealed short-life expectancy, hence herbal products attracts the attention of the researchers to develop new antimicrobial drugs (Khan et al., 2009).

Acacia nilotica (L.) Willd. ex Del. var. nilotica belong to family Fabaceae. It is a widely spread tree in the central and northern parts of the Sudan, known in Sudanese folk medicine as 'kaarad' (Abd-El-Nabi et al., 1992). There are around 1300 species of Acacia species found all over the world distributed in dry tropical and sub-tropical regions including Africa, Australia, India, Southern Asia and Americas (Auwal et al., 2015). Acacia trees are important environmental and economic plants. They are multi-purpose nitrogen fixing tree legumes, they are also a source of Arabic gum, wood, fuel, tannins and medications since ancient times (Bargali and Bargali, 2009). The fruits of Acacia nilotica are linear and narrow, flattened pods (Fig. 1), 
its pods, about 4-22 cm in length and $1-2 \mathrm{~cm}$ in diameter, contains 8-15 elliptical bean-shaped and dark brown to gray in color and Velvety texture (Kumar, 2015). In Sudanese folk medicine, the fruits (pods) of Acacia nilotica are used as aqueous macerates or in a powder form for treatment of pneumonia, tonsillitis, dysentery, diarrhea and malaria (Ebrahim et al., 2012). The phytochemical studies on the pods of Acacia nilotica showed some bioactive principles such as tannins, saponins, glycosides and flavonoids (Auwal et al., 2015). A recent study showed that the pods of Acacia nilotica have potential antioxidant and found effective in protecting plasmid DNA and human serum albumin protein oxidation induced by hydroxyl radicals (Singh et al., 2009). The present study was conducted to evaluate the efficacy of pods of Acacia nilotica as an antibacterial drug traditionally used in Sudanese folk medicine.

\section{Materials and methods}

\section{Plant material}

Dried pods of Acacia nilotica were purchased from a famous herbal market from Khartoum city (Fig. 1), authenticated by botanist (Dr. Wail E. Abdalla). Pods were washed thoroughly with tap water followed with sterilized distilled water and left to dry in oven at $50^{\circ} \mathrm{C}$ for few days, seeds were separated from the dried pods and excluded and ground using a blender, sieved and fine powder was collected and saved dark well-tighten container and kept until used.

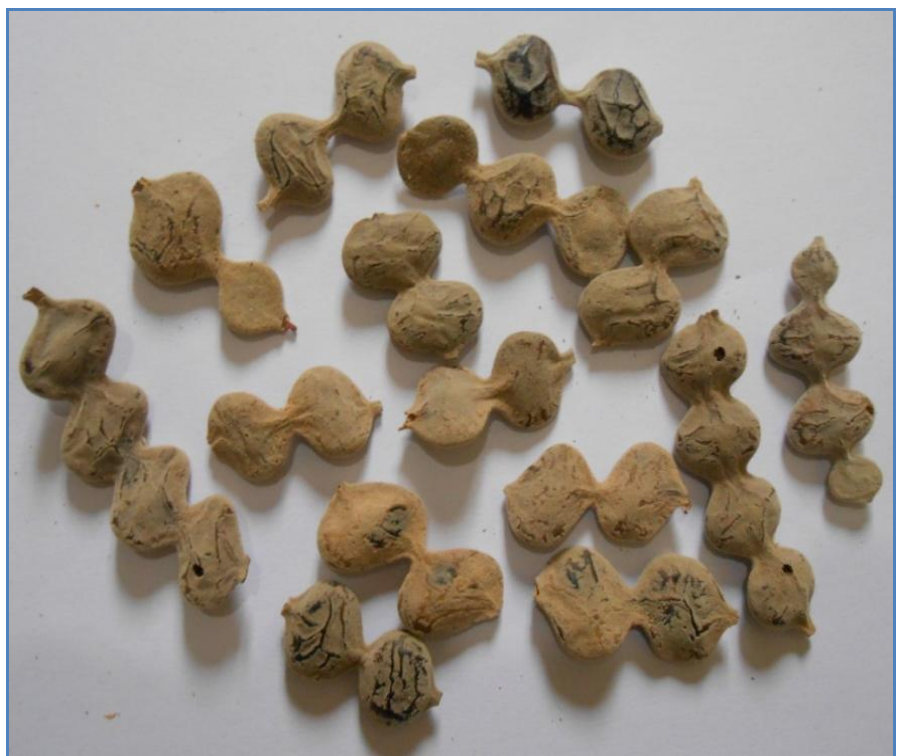

Fig. 1: The pods of Acacia nilotica, selected for the present study.

\section{Bacterial cultures}

Referenced bacterial strain, Bacillus cereus ATCC 11778 (Remel Europe, LTD, UK) was previously purchased from Watin-Biolife, KSA. Other bacteria were clinical isolates collected and routinely identified by Dr. Fiaz Ahamed, from Al-Rass General Hospital, Pathology and Laboratory medicine, Saudi Arabia. Those bacteria were Staphylococcus aureus, Escherichia coli and Acinetobacter baumannii. All bacteria were maintained on Mueller Hinton agar slants in a refrigerator at $4^{\circ} \mathrm{C}$ until required.

\section{Plant extraction}

$100 \mathrm{~g}$ of the dried powder of Acacia nilotica pods was weighted and put in a sterile glass container. Then, 500 $\mathrm{ml}$ of $80 \%$ methanol was slowly added, tightly closed, shake vigorously two or three times a day. This action was repeated for up to 3 days. After that, the macerate was filtered using Whatman filter papers No.1, the filtrate was separated and stored in the incubator $45^{\circ} \mathrm{C}$ for up to 7 days to get dry extract. At the time of antibacterial experiment, two concentrations were prepared (400 and $200 \mathrm{mg} / \mathrm{ml}$ ) by reconstituting the crude extract in absolute methanol.

\section{Preparation of inoculums}

The tested bacteria were sub-cultured in nutrient broth for about $18 \mathrm{~h}$ at $37^{\circ} \mathrm{C}$ to reach the exponential phase and then adjusted to $0.5 \mathrm{McF}$ arland's standard, using sterile normal saline, to get bacterial density equivalent to approximately $1.0 \times 10^{8} \mathrm{cfu} / \mathrm{ml}$, and directly employed in the antibacterial testing.

\section{Disc diffusion method}

The antibacterial activity of methanol extract of Acacia nilotica pods was determined using a modified KirbyBauer disc diffusion method as reported by Kowti et al. (2010), with some modifications; In aseptic conditions, $20 \mathrm{ml}$ of warm Mueller Hinton agar (Watin-Biolife, KSA), was poured on sterile disposable plates (Jalil Medicals) and left at room temperature to solidify, Then turned upside down and kept in the refrigerator for about halve hour. $100 \mu \mathrm{l}$ of the bacterial suspensions (previously adjusted) were swapped onto the Mueller Hinton plates, using sterile cotton swaps. Sterile blank discs of $6 \mathrm{~mm}$ were previously prepared from Whatman No.1 filter paper (Sigma-Aldrich) and saturated with 400 and $200 \mathrm{mg} / \mathrm{ml}$ to trap about 8 and $4 \mathrm{mg} / \mathrm{disc}$, respectively (Pre-experimental measurements showed 
that the $6 \mathrm{~mm}$ disc absorb about $20 \mu \mathrm{l})$. Saturated discs were placed onto inoculated plates, the plates were allowed to stand for a while at room temperature, and then incubated at $37^{\circ} \mathrm{C}$ for $24 \mathrm{hrs}$. The susceptibility of the tested bacteria to the extract was indicated after incubation by zones of growth inhibition in millimeter (mm) using a transparent ruler. Gentamicin discs (10 $\mu \mathrm{g} /$ disc) (Oxoid), were used as standard antibacterial (positive control), another discs saturated with the solvent (methanol) were loaded in a separate inoculated plates and served as negative control.

\section{Determination of minimum inhibitory concentration}

The Minimum inhibitory concentration (MIC) of the methanol extract of Acacia nilotica pods against the tested bacteria was evaluated as described by Abubakar (2009). $1 \mathrm{ml}$ of the crude extract at a concentration of $400 \mathrm{mg} / \mathrm{ml}$ was added to a tube containing $1 \mathrm{ml}$ Mueller Hinton broth (Watin- Biolife, KSA). Then, $1 \mathrm{ml}$ from this tube (First tube) was transferred to the next one in two folds serial dilutions till reached the $7^{\text {th }}$ tube, to get the concentrations 400, 200, 100, 50, 25, 12.5 and 6.25, respectively. To additional tube $1 \mathrm{ml}$ of absolute methanol was loaded instead of the plant extract and served as negative control. Also, another tube containing Mueller Hinton broth only and inoculated with the test bacteria was considered as positive control. All tubes were kept in the incubator (BINDER GmbH, Germany) at $37^{\circ} \mathrm{C}$ for about $24 \mathrm{~h}$. After incubation, all tubes were inspected visually for bacterial growth by observing formation of turbidity on the test tubes compared to the controls. The least concentration of the plant extract that did not show any visible growth was considered as MIC.

\section{Determination of minimum bactericidal concentration}

The Minimum bactericidal concentration (MBC) of the methanol extract of Acacia nilotica pods against tested bacteria were carried out according to Doughari and Manzara (2008) with minor modification. From the MIC tubes that shows no visible growth, $100 \mu \mathrm{l}$ from each of them was loaded on Mueller Hinton agar plates, swapped with sterile cotton stick, incubated overnight at $37^{\circ} \mathrm{C}$ and inspected for growth. The least concentration that showed no single bacterial colony on the agar plate was considered as MBC.

\section{Statistical analysis}

SPSS statistical analysis software package (Version 17) was used for interpretation of the results. Descriptive statistics was used to get means \pm standard error of means, One-Way ANOVA for disc diffusion, MIC and $\mathrm{MBC}$ results and two tailed partial correlation test for comparison between 8 and $4 \mathrm{mg} /$ disc methanol plant extracts. A value of $p<0.05$ was considered significant.

\section{Results and discussion}

The antibacterial activity of the methanol extract of Acacia nilotica pods against tested bacteria was initially performed using the modified Kirby-Bauer disc diffusion method (Fig. 2), as shown from Table 1 and Fig. 3, no significant differences detected of the disc diffusion test between 8 and $4 \mathrm{mg} /$ disc plant extract $(6 \mathrm{~mm}$ Whatman filter paper disc No. 1). It is thought that such disc size cannot trap $8 \mathrm{mg} / \mathrm{disc}, 4$ or $5 \mathrm{mg} / \mathrm{disc}(6 \mathrm{~mm}$ in diameter) may be the maximum amount. The KirbyBauer disc diffusion method is invented basically for antibiotics sensitivity testing.

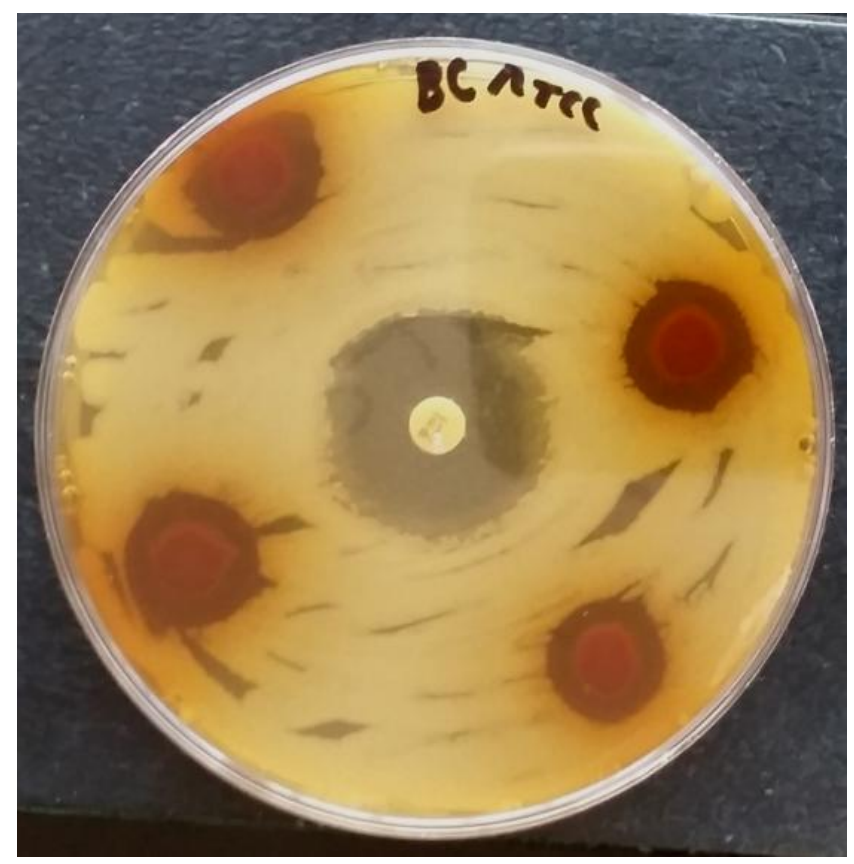

Fig. 2: Representative photo showing the antibacterial activities of methanol extract of Acacia nilotica pods against Bacillus cereus compared to Gentamicin.

Accordingly, standardization and adjustment of KirbyBauer assay to be suitable for investigate the unknown crude plant extract are required. The results also showed that the most susceptible bacteria (at $400 \mathrm{mg} / \mathrm{ml}$ ) was Escherichia coli $(20.5 \pm 1.5 \mathrm{~mm})$, followed by Staphylococcus aureus $(19.5 \pm 0.5 \mathrm{~mm})$, Acinetobacter baumannii $(18.5 \pm 0.5 \mathrm{~mm})$ and Bacillus cereus ATCC

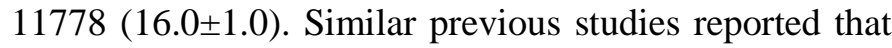
the pods of Acacia nilotica have antibacterial effects; 
This is in harmony with the findings of El-Kamali and El-karim (2009) whom published that the ethyl acetate and the methanol extracts of the pods of the Sudanese Acacia nilotica, recorded broad spectrum antibacterial activity against Staphylococcus aureus (ATCC 25923), Bacillus subtilis (NCTC 8236), Escherichia coli (ATCC 25922), Proteus vulgaris (ATCC 6380), Pseudomonas aeruginosa (ATCC 27853) and Klebsiella pneumoniae (ATCC 1312).

Also, Abd-El-Nabi et al. (1992) mentioned that the aqueous extract of Acacia nilotica pods collected from Sudan revealed antibacterial activity against 10 bacterial cultures representing gram negatives and gram positives. The current results also showed that, the susceptibility of gram negative bacteria was relatively higher than the,
Statistical analysis showed that there is no significant differences between the zone of growth inhibition between gram-negative and gram positive bacteria $(p<0.05)$, meaning that this plant extract may have broad spectrum effect against human pathogens.

However, Mustafa et al. (1999) cited that water, ethanol, $n$-hexane and chloroform extracts of Acacia nilotica pods were more effective against Gram positive cocci than Gram-negative bacilli. On the other hand, gentamicin recorded significant differences $(p<0.05)$, which means that this antibiotic is losing gradually its broad spectrum properties. Gentamicin is an aminoglycoside antibiotic with broad-spectrum activity, it inhibits protein synthesis by binding irreversibly to $30 \mathrm{~S}$ bacterial ribosome (Nahum et al., 2006).

Table 1. The antibacterial activity of methanol extract of methanol extract of Acacia nilotica pods by disc diffusion method.

\begin{tabular}{|c|c|c|c|c|}
\hline \multirow{2}{*}{ Test } & \multicolumn{4}{|c|}{ Mean zone of growth inhibition (mm) } \\
\hline & Staphylococcus aureus & Bacillus cereus & Escherichia coli & Acinetobacter baumannii \\
\hline $\begin{array}{l}\text { Methanol extract } \\
(400 \mathrm{mg} / \mathrm{ml} \text { or } 8 \mathrm{mg} / \mathrm{disc})\end{array}$ & $19.5 \pm 0.5$ & $16.0 \pm 1.0$ & $20.5 \pm 1.5$ & $18.5 \pm 0.5$ \\
\hline $\begin{array}{l}\text { Gentamicin } \\
(10 \mu \mathrm{g} / \text { disc })\end{array}$ & $25 \pm 0.0$ & $26 \pm 0.0$ & $18.0 \pm 0.0$ & $6.0 \pm 0.0$ \\
\hline
\end{tabular}

* Inhibition zones are the mean including disc diameter $(6 \mathrm{~mm}) \pm$ standard error of means, $6.0=$ no inhibition, $\mathrm{mm}=$ millimeter, test repeated twice.

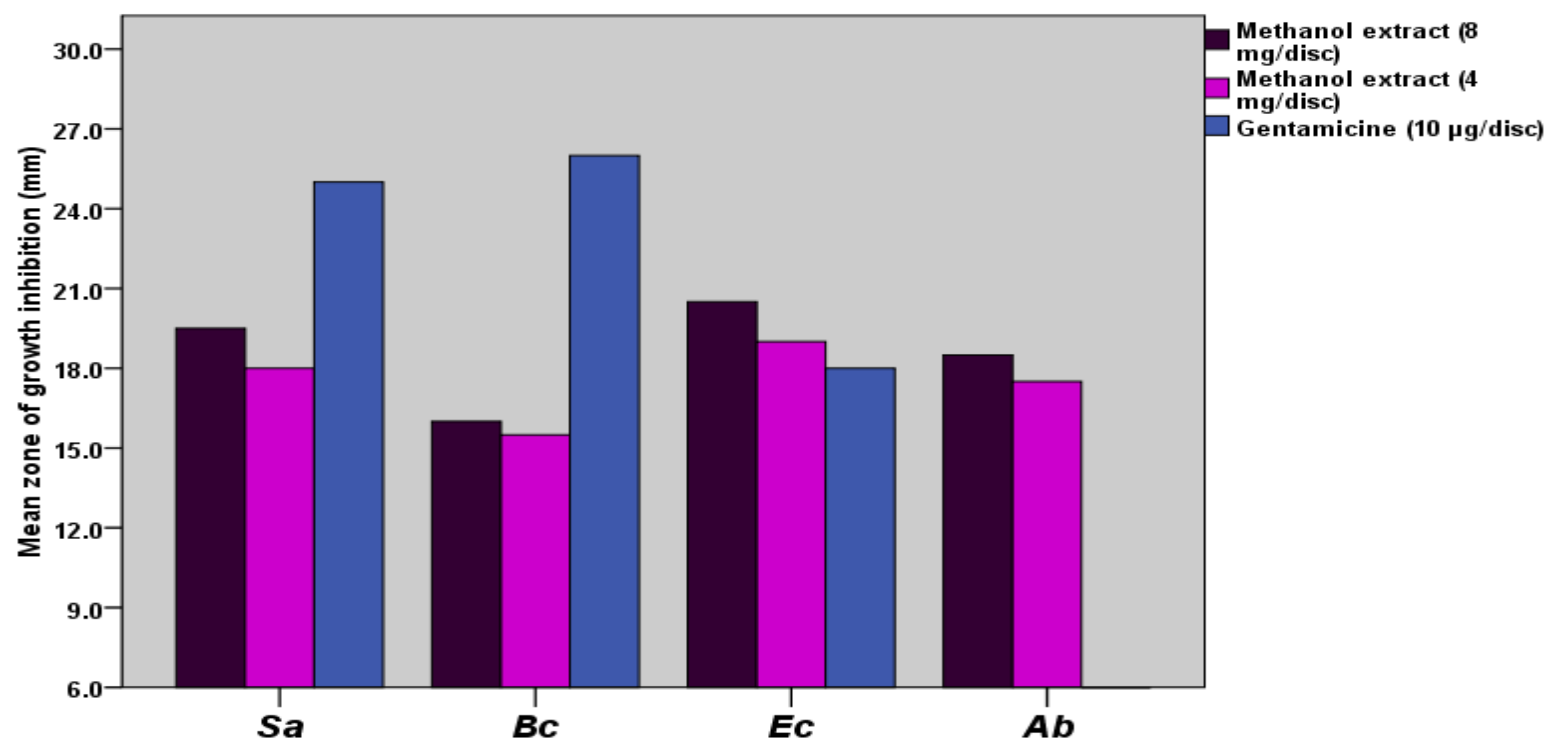

Fig. 3: The antibacterial efficacy of methanol extract of Acacia nilotica pods compared to Gentamicin*. * The diameter of the paper disc (6 mm) was omitted, Sa= Staphylococcus aureus, Bc=Bacillus cereus, Ec= Escherichia coli, Ab= Acinetobacter baumannii . 
The antibacterial efficacy of this extract was also evaluated by MIC and MBC assays, as shown in Table 2. The results revealed that the pod extract of Acacia nilotica represented effective bacteriostatic activity against all tested bacteria, even at low concentration $(12.5 \mathrm{mg} / \mathrm{ml})$ against the gram-positive bacteria, in particular. The MBC values were equal to or greater than the MIC (Table 2). Actually, the closer in value of the MBC to MIC the more bactericidal, if the MIC value of the plant extract is also the MBC value or higher, it means good sign of bactericidal effect. This is in agreement to some extend with Auwal et al. (2015) who stated that the MIC and MBC of pods of Acacia nilotica aqueous extract were 25 and $25 \mathrm{mg} / \mathrm{ml}$ for Bacillus subtilis and Klebsiella pneumoniae, and 200 $\mathrm{mg} / \mathrm{ml}$ for Staphylococcus aureus, respectively. Accordingly, the methanol extract of Acacia nilotica pods have potential bactericidal effect against all tested bacteria, being much bactericidal against the grampositives. Finally, the pods of this plant are definitely considered promising source of effective antibacterial drug. The interesting outcomes of this investigation providing encourages the antibiotics-researchers to give more attention to the natural plant products particularly those mentioned or applied in traditional or folk medicine.

Table 2. The minimum inhibitory concentration (MIC) and minimum bactericidal concentration (MBC) of crude methanol extract of Acacia nilotica pods.

\begin{tabular}{lll}
\hline Microorganism & MIC $(\mathbf{m g} / \mathbf{m l})$ & MBC $(\mathbf{m g} / \mathbf{m l})$ \\
\hline Staphylococcus aureus & 12.5 & 50 \\
Bacillus cereus & 12.5 & 50 \\
Escherichia coli & 100 & 100 \\
Acinetobacter baumannii & 50 & 100 \\
\hline
\end{tabular}

\section{Conclusion}

The pods of Acacia nilotica methanol extract was found to be effective as antibacterial against different bacterial pathogens, providing the scientific basis for its traditional application in Sudanese folk medicine against many bacterial diseases. Further studies should be done to find out the active compound responsible for antibacterial effects as well as toxicological and other necessary pharmacological studies to use in modern drugs developments.

\section{Conflict of interest statement}

Author declares that there is no conflict of interest.

\section{Acknowledgement}

Author would like to thank Dr. Wail E. Abdalla for plant identification and Dr. Fiaz Ahamed for clinical bacterial isolates.

\section{References}

Abdallah, E.M., 2011. Plants: An alternative source for antimicrobials. J. Appl. Pharmaceut. Sci. 1(6), 16-20.

Abd-El-Nabi, O.M., Reisinger, E.C., Reinthaler, F.F., Still, F., Eibel, U., Krejs, G.J., 1992. Antimicrobial activity of
Acacia nilotica (L.) Willd. ex Del. var. nilotica (Mimosaceae). J. Ethnopharmacol. 37, 77-79.

Abubakar, E. M., 2009. Antibacterial efficacy of stem bark extracts of Mangifera indica against some bacteria associated with respiratory tract infections. Scient. Res. Essay. 4(10), 1031-1037.

Ackerknecht, E. H., 1973. Therapeutics: From the Primitive to the Twentieth Century. $1^{\text {st }}$ Edn., Hafner Press, New York, USA.

Auwal, M.S., Shuaibu, A., Ibrahim, A., Mustapha, M., 2015. Antibacterial properties of crude pod extract of Acacia nilotica (Fabaceae). Haryana Veterin. 54(1), 29-32.

Bargali, K., Bargali, S.S., 2009. Acacia nilotica: a multipurpose leguminous plant. Nature Sci. 7(4), 11-19.

Doughari, J.H., Manzara, S., 2008. In vitro antibacterial activity of crude leaf extracts of Mangifera indica Linn. Afr. J. Microbiol. Res. 2, 67-72.

Ebrahim, A.M., Eltayeb, M.H., Khalid, H., Mohamed, H., Abdalla, W., Grill, P., Michalke, B., 2012. Study on selected trace elements and heavy metals in some popular medicinal plants from Sudan. J. Natural Med. 66(4), 671-679.

El-Kamali, H.H., El-Karim, E.M.A., 2009. Evaluation of antibacterial activity of some medicinal plants used in Sudanese traditional medicine for treatment of wound infections. Acad. J. Plant Sci. 2(4), 246-251.

Khan, R., Islam, B., Akram, M., Shakil, S., Ahmad, A., Ali, S.M., Siddiqui, M., Khan, A.U., 2009. Antimicrobial activity of five herbal extracts against multi drug resistant (MDR) strains of bacteria and fungus of clinical origin. Molecules. 14(2), 586-597.

Kowti, R., Harsha, R., Ahmed, M.G., Hareesh, A.R., Thammanna Gowda S.S., Dinesha, R., Satish Kumar, B.P., 
Irfan, A.M., 2010. Antimicrobial activity of ethanol extract of leaf and flower of Spathodea campanulata P. Beauv. Res. J. Pharmaceut. Biol. Chem. Sci. 1(3), 691-698.

Kumar, M., 2015. Acacia nilotica Linn. as a phytomedicine: An overview. Int. J. Drug Disc. Herbal Med. 5(1): 843848.

Mustafa, N.K., Tanira, M.O.M., Dar, F.K., Nsanze, H., 1999. Antimicrobial activity of Acacia nilotica subspp. nilotica fruit extracts. Pharm. Pharmacol. Commun. 5 (9), 583-586.
Nahum, G.G., Kalhleen, U.H.L., Kennedy, D.L., 2006. Antibiotic use in pregnancy and lactation what is and is not known about teratogenic and toxic risks. Obstet. Gynecol. 107(5), 1120-1138.

Singh, B.N., Singh, B.R., Singh, R.L., Prakash, D., Sarma, B.K., Singh, H.B., 2009. Antioxidant and anti-quorum sensing activities of green pod of Acacia nilotica L. Food Chem. Toxicol. 47(4), 778-786.

\section{How to cite this article:}

Abdallah, E. M., 2016. Antibacterial efficacy of Acacia nilotica pods, growing in Sudan against some bacterial pathogens. Int. J. Curr. Res. Biosci. Plant Biol. 3(3), 6-11. doi: http://dx.doi.org/10.20546/ijcrbp.2016.303.002 